\title{
Growth Performance, Nutrient Digestibility and Carcass Characteristics of Pigs Fed Diets Containing Amarula (Sclerocarya Birrea A. Rich) Nut Cake as Replacement To Soybean Meal
}

\author{
Maggy Palesa Mabena \\ Animal Production Institute \\ Moses Ratsaka \\ Tshwane University of Technology \\ Thobela Nkukwana \\ university of Pretoria

\section{Ingrid Malebana} \\ animal production institute \\ Douglas Nkosi ( $\square$ dnkosi@arc.agric.za ) \\ Animal Production Institute https://orcid.org/0000-0002-6957-9562
}

\section{Research Article}

Keywords: energy, fats, fibre, meat, nitrogen, soybean

Posted Date: June 22nd, 2021

DOI: https://doi.org/10.21203/rs.3.rs-582720/v1

License: @ (1) This work is licensed under a Creative Commons Attribution 4.0 International License. Read Full License

Version of Record: A version of this preprint was published at Tropical Animal Health and Production on December 10th, 2021. See the published version at https://doi.org/10.1007/s11250-021-03016-3. 


\section{Abstract}

This experiment evaluated varying levels of Amarula (Sclerocarya birrea A. Rich) nut cake (ANC) on growth performance, nutrient digestibility and carcass characteristics in pigs. Thirty Large White $\times$ Landrace $(L W \times L R)$ pigs were stratified by weight (average live weight of $20 \pm 5 \mathrm{~kg}$ ) and randomly allocated to the five experimental diets that contained 0 (control), 50, 100, 150 and $200 \mathrm{~g} \mathrm{ANC/kg} \mathrm{DM.} \mathrm{Each} \mathrm{pig} \mathrm{served} \mathrm{as} \mathrm{a} \mathrm{replicate} \mathrm{unit,} \mathrm{housed}$ individually. Bodyweight, feed intake, average daily gain (ADG) and feed conversion ratio (FCR) were recorded weekly throughout the trial period. On completion of the growth trial, following a 3-day adaptation, a nutrient digestibility study was conducted over 5 days. Thereafter, pigs were fasted for twelve hours, weighed, slaughtered, and carcass samples were collected for analysis. Feed intake was not affected by dietary treatment, but ADGs were reduced at ANC levels $>15 \%$, resulting in poor FCR. Protein digestibility was reduced at ANC levels $>15 \%$, while ether extract and fibre levels increased. Warm and cold carcass weights were lower at ANC levels $>15$, with improved meat redness and lightness. It was concluded that ANC could replace SBM in the diet of growing pigs at less than $15 \%$ inclusion level.

\section{Introduction}

Soybean meal (SBM) is the mostly used protein source in animal nutrition, due to its high quality in amino acid profile (McDonald et al., 2011), and accounts for 85 \% of the protein supplements fed to pigs (Cortamira et al., 2000). The majority (72 \%) of SBM supplies in South Africa is imported from non-African countries (Sihlobo and Kapuya, 2016), making it difficult to be afforded by some pig producing farmers, especially those in the emerging sector. Consequently, researchers in animal nutrition have attempted to identify protein source alternatives to SBM to reduce feed costs. However, performance results of pigs from dietary replacement of SBM with other protein sources are variable. Some researchers (e.g. Choi et al., 2015) reported reduced pig growth performance while others did not report any significance when SBM was substituted in the diet (Florou-Paneri et al., 2014). This depends mainly on the balance or imbalances of amino acids in the diets (McDonald et al., 2010) and the presence of anti-nutritional factors (ANFs) in the diet (Choi et al., 2015) when SBM is replaced with other crude protein (CP) sources.

The banning of the use of protein sources from animal origin in animal feed during the year 2001 increased the demand for locally produced plant protein sources in South Africa. Due to the shortage in local production and increasing imports of SBM, the possibility of replacing SBM with other plant protein sources from local oil production, can contribute to sustainable pig production. It is thus important to evaluate the nutritional value of locally produced plant protein sources. Amarula (Sclerocarya birrea A. Rich) nut cake (ANC) is a by-product that is derived from oil extraction of the dry seeds of ripe amarula fruit, an indigenous fruit tree that is widely distributed throughout the Sub-Saharan Africa (Mthiyane and Mhlanga, 2017). Research has shown that ANC contains crude protein (CP) that ranges from 325 to $470 \mathrm{~g} / \mathrm{kg}$ dry matter (DM) (Mthiyane and Mhlanga, 2017, Malebana et al., 2018, Nkosi et al., 2019), comparable to that of SBM, but higher than that of other conventional protein sources such as canola seed meal ( $270 \mathrm{~g} \mathrm{CP} / \mathrm{kg} \mathrm{DM}, \mathrm{NRC}, 2001)$. The ANC contains ether extract (EE) that ranges from 344 to $498 \mathrm{~g} \mathrm{EE} / \mathrm{kg}$ DM (Mthiyane and Mhlanga, 2017, Malebana et al., 2018, Nkosi et al., 2019), which depends on the processing method for oil extraction (Malebana et al., 2018). The high fat content in ANC could provide sufficient energy in diets and allow pigs to improve feed efficiency, daily gains and thus increase muscle accretion (De la Llata et al., 2001, Stephenson et al., 2016). 
Previous studies showed that ANC could be a good source of CP in diets for ruminants (Mlambo et al., 2011, Mdziniso et al., 2016) and for poultry (Mthiyane and Mhlanga, 2017, Mazizi et al., 2019) without adverse effects on animal performance. According to Mthiyane and Mhlanga (2017) and Mazizi et al. (2019) one of the benefits for dietary addition of ANC in animal diets is the increase in oleic acid content in the meat of birds, which is a potential health benefit to consumers. It has not yet been determined how much SBM can be replaced by non-conventional ANC in diets for growing pigs without affecting growth performance or carcass characteristics. The hypothesis that ANC would be safe as feedstuff for growing pigs, support adequate growth performance, and enrich the carcass with lean meat was tested. The objectives of this study were therefore to evaluate the effects of feeding increasing inclusions levels of ANC in diets on growth performance, nutrient digestibility and carcass characteristics of pigs.

\section{Materials And Methods}

\section{Study site and management of animals}

The study was conducted at the Pig Nutrition Section of the Agricultural Research Council (ARC)-Irene Campus, South Africa (longitude $25^{\circ} 55^{\prime} \mathrm{S} ; 28^{\circ} 12 \mathrm{E}$ ). Amarula nut cake (ANC) was sourced from African Exotic Oils, Phalaborwa, Limpopo Province, South Africa. The ANC nutrient composition was analysed at ARC-Irene Campus, and was used to formulate the five experimental diets (Table 1) that contained ANC at 0 (control), 50, 100, 150 and $200 \mathrm{~g} / \mathrm{kg} \mathrm{DM}$; respectively. The diets were formulated to be isoenergetic and isonitrogenous to provide $14 \mathrm{MJ} / \mathrm{kg}$ digestible energy (DE), $180 \mathrm{~g} / \mathrm{kg}$ crude protein (CP) g/kg and $11.6 \mathrm{~g} / \mathrm{kg}$ lysine for growing pigs. The thirty LW $\times$ LR pigs with an average body weight of $20 \pm 5 \mathrm{~kg}$ were randomly allocated to the experimental diets (treatments) in a completely randomized block design. The pigs were housed individually in $1.54 \times 0.8 \mathrm{~m}$ pens in environmentally controlled houses with temperatures ranging from 22 to $25^{\circ} \mathrm{C}$. The pigs were weighed once every week. The feeders were adjusted twice each day to ensure constant access to fresh feed and minimize any possible wastage. The pigs also had free access to water.

\section{Nutrient digestibility}

A week after completion of the growth study, digestibility study carried out. In brief, chromic oxide was mixed with the treatments at a concentration of $3 \mathrm{~g}$ chromic oxide/ $\mathrm{kg}$ feed as an indigestible marker as described by Moughan et al. (1991). The pigs were allowed an adaptation period of 3 days to the chromic oxide mixed diets before collection of faecal samples for 5 days using the grab sampling method was carried out according to Moughan et al. (1991). The faecal samples were collected once per day, weighed and DM determined. The samples were then freeze-dried, ground and stored at $-20^{\circ} \mathrm{C}$ in $250 \mathrm{ml}$ plastic containers until further analysis. Both diets and faecal samples were analysed for DM, crude protein (CP), gross energy (GE), ash, EE and fibre fractions [neutral detergent fibre (NDF), acid detergent fibre (ADF) and acid detergent lignin (ADL)] following the standard procedures of AOAC (2003).

\section{Animal processing and carcass measurements}

At the end of the nutrient digestibility study, pigs were fasted for 12 hours and weighed to determine the final weight. The pigs were then transported to the Irene Campus's abattoir for slaughtering. Prior to being slaughtered, the pigs were handled according to the routine abattoir procedures, which included rest for the pigs before slaughter and ante-mortem inspection. The pigs were then stunned with an electrical stunner set at 220V and 1.8A with a current flow for $6 \mathrm{~s}$ and exsanguinated within 10 s of stunning. The head from each carcass was then removed at the 
atlanto-occipital joint and the tail at the junction of the third and fourth sacral vertebrae. Carcass dressing and evisceration were done according to the abattoir`s standard operating procedures.

Following carcass dressing and evisceration, carcass length was measured from the first rib to the pubic bone along the median plane using a measuring tape, followed by measurement of warm carcass weight (WCW) using an overhead scale. Warm carcass temperature and $\mathrm{pH}\left(\mathrm{pH}_{\mathrm{i}}\right)$ were measured on each of the carcasses' Longissimus thoracis muscle (eye muscle) with a portable $\mathrm{pH}$ meter between the third and the fourth rib, $60 \mathrm{~mm}$ from the midline. Dressing percentage (DP) of each carcass was calculated as described by Bonvillani et al. (2010).

The carcasses were then stored in a cold room at a temperature of $0^{\circ} \mathrm{C}$ for 24 hours, after which cold carcass weight (CCW) of each carcass was measured. After determination of cold carcass weight, cold carcass temperature and $\mathrm{pH}$ $\left(\mathrm{pH}_{\mathrm{u}}\right)$ as measured on the Longissimus thoracis muscle. Back fat thickness was measured between the 2nd and 3rd ribs about $60 \mathrm{~mm}$ from the midline on the left carcass using a pair of Vernier Calipers (Bruwer et al., 1991). The rib was cut between the 4th and 12th thoracic vertebrae dorsally and along a parallel line $(16 \mathrm{~cm})$ from the spinal cord midline ventrally. The rib was then weighed using a digital scale to obtain the rib weight. The hind leg was removed between the 2nd and 3rd sacral vertebrae perpendicular to the stretched leg and at the hock joint distally and weight to determine the hindquarter weight (HQW). The hid leg was also measured from the ischiopubic symphysis to the hock joint to determine the hindquarter length (HQL) using a measuring tape.

\section{Drip loss determination}

An $80 \mathrm{~g}$ chop was cut from the Longissimus dorsi muscle between the 4th and 8th ribs of each carcass and used to determine drip loss (DL) of the muscles. Each chop sample was placed in a nylon mesh and then sealed in a preweight plastic bag for a period of $24 \mathrm{hrs}$ at $2^{\circ} \mathrm{C}$. After 24 hours, each sample was taken out of the plastic bag and reweighed. Drip loss was calculated according to the method described by Choi and Oh (2016), using the equation: Drip loss = Final weight of sample / Initial weight of sample $\times 100$.

\section{Meat colour determination}

Meat colour was measured using a Minolta colour meter (Model CR200, Osaka, Japan) according to Krzywicki (1979). Chops samples (40 g) from the longissimus dorsi muscle were used to measure the meat colour. The three fundamental colour constituents $\left(L^{*}, a^{*}\right.$ and $\left.b^{*}\right)$ were evaluated wherein $L^{*}$ indicates lightness on a scale of 0 to $100 ; a *$ indicates red to green colour, and $b *$ indicates yellow to blue colour. The chop samples were placed on a tray to bloom for $1 \mathrm{~h}$ at $4^{\circ} \mathrm{C}$. After $1 \mathrm{~h}$ of blooming, meat colour was measured at three different locations of each chop.

\section{Statistical analysis}

The experiment was carried out as a randomized blocked design (RBD) with five treatments randomly allocated in 6 blocks. ANOVA (Analysis of Variance) was used to test the differences between the five treatments effects in order to determine the growth performance, nutrient digestibility and carcass characteristics in pigs (Snedecor and Cochran, 1980). To test for deviations from normality, Shapiro-Wilk's test was performed on the standardized residuals (Shapiro and Wilk, 1965). In cases where significant deviation from normality was evident and the deviation was due to skewness, the outliers were removed until the data was normally or symmetrically distributed (Glass et.al. 1972). Student's t-LSD (Least significant difference) were calculated at a $5 \%$ confidence level to compare treatment means (Snedecor and Cochran, 1980). All the above data analysis was performed with SAS version 9.4 statistical software (SAS, 2016). 
Data on the effects of treatments on growth performance, nutrient digestibility and carcass characteristics were fitted with the following model: $Y_{i j}=\mu+t_{i}+ß_{j}+\varepsilon_{i j}$

where: $Y_{i j}$ is the individual observations of the $\mathrm{i}$-th treatment and the $\mathrm{j}$-th replicate, $\mu$ is the overall mean, $t_{i}$ is the effect of the $\mathrm{i}$-th treatment, $\beta_{\mathrm{j}}$ is the effect of the $\mathrm{j}$-th block replicate, and $\varepsilon_{i j}$ is the residual error.

\section{Results}

Increasing dietary inclusion of ANC increased $(\mathrm{PO}<05)$ the ether extract, energy and fibre while reducing the $\mathrm{CP}$ contents of the diets (Table 4). Inclusion of ANC reduced compositions of lysine and threonine in the diets (Table 5). The ADFI (average daily feed intake) was not affected by dietary treatments (Table 6). However, the ADG and BWG (body weight gain) were reduced with more than $15 \%$ dietary inclusion of ANC, which further resulted in a poor FCR. The digestibility of DM was not affected by the dietary treatments (Table 7). However, the digestibility of CP was reduced while that of EE and fibre was improved with increased (>15\%) dietary ANC.

Warm and cold carcass weights were reduced with increased (> 15\%) dietary ANC (Table 8). The warm and cold carcass temperature and $\mathrm{pH}, \mathrm{DP}$, back fat thickness, eye muscle area, drip loss were not affected by the dietary treatments. The redness $\left(a^{*}\right)$ and lightness $\left(L^{*}\right)$ of the meat sample was improved $(P<0.05)$ with increased dietary inclusion of ANC, while the yellowness ( $\left.b^{\star}\right)$ was not affected by the dietary treatments (Table 9 ).

\section{Discussions}

It should be noted that the SBM used in the present study comes from the same batch with that used by Malebana et al. (2018). Although ANC has lower CP compared to SBM (Malebana et al., 2018), the CP of ANC (Table 1) is still advantageous to other conventional feed resources such as maize and sunflower meal that contain almost half or even lower CP content than the ANC. The increased fat and energy content with ANC inclusion in the diet (Table 4) is due to the fact that ANC contains higher residual oil and thus energy, but lower CP content compared to SBM (Malebana et al., 2018). Lysine is the first limiting amino acid in pigs and the ANC contains $6.8 \mathrm{~g} l y s i n e / \mathrm{kg}$ (Table 2), which is lower than $31 \mathrm{~g}$ lysine/kg reported in SBM by Malebana et al. (2018).

Under adequate feeding and management systems, growing pigs are expected to have an average daily gain of 640 $\mathrm{g} / \mathrm{d}$ (Payne, 1990). Pigs in the present study had ADG that meets this benchmark except for those that were fed diets that contained $>15 \%$ ANC, which were lower than this benchmark. In a study by Smit and Beltranena (2017), dietary addition of $15 \%$ of Camelina cake (a by-product with an oil content of between 10 and $20 \%$ and CP of $>30$ \%) (Pekel et al., 2015) decreased the ADFI, ADG and body weights (BW) of growing pigs. Results by Smit and Beltranena (2017) concurred with the findings of the current study when more than $15 \%$ of ANC is added to the pig diets. Pig diets containing $15.5 \%$ of moringa oleifera as a replacement to SBM resulted in a lower ADFI due to increased dietary fibre (Ruckli and Bee, 2016). Results in this study show that feed intake was not affected by the dietary treatments although the inclusion of ANC increased the dietary fibre in the treatments.

The lower ADG in pigs fed diets containing > $15 \%$ ANC might be attributed to the increased dietary fibre in the treatments, which increased energy requirements for body maintenance at the expense of growth (Agyekum et al., 2015). Mthiyane and Mhlanga (2017) reported the negative effects of ANC on growth performance of broiler chickens to be related to extensive lipid peroxidation of the ANC. Feeding of oxidised lipids has been reported to reduce daily gains, which leads to poor feed efficiency. Unfortunately, lipid peroxidation of ANC was not determined in the present study. It is well documented that pigs fed high fibre diets are heavier in relation to those fed low fibre diets (e.g. Thacker and Campbell, 1999). This could be because of the increased weight of the pigs' visceral organs 
and the gastro-intestinal tract (Len et al., 2008). In contrast, the final body weights of pigs fed increased dietary inclusion levels of ANC was reduced (Table 6), which might be related to the reduced CP digestibility and ADG by the pigs. According to the National Research Council (NRC, 1998), an intake of $2320 \mathrm{~g} / \mathrm{d}$ is recommended for finishing pigs. Pigs in the present study had a daily feed intake (DFI) that ranged from 1500 to $1700 \mathrm{~g} / \mathrm{d}$, which is lower than the reported value. The low DFI by pigs in the present study could be attributed to the pigs' lower initial body weights than to those reported by the NRC (1998) for finishing pigs. Reduced ADFI by pigs fed the ANC diets was expected due to increased dietary fat compared to the control. This is because pigs often reduce intake as the dietary energy concentration increases (Liu et al., 2019). Surprisingly, the ADFI was not affected by the dietary treatments.

The digestibility of nutrients in a diet is mostly affected by the composition of the nutrients as well as ANFs in the nutrients. In most cases, dietary fibre has been reported to reduce nutrient digestibility in monogastric animals (e.g. pigs). Galassi et al. (2010) reported a trend towards a reduction in nutrient digestibility by pigs with increasing dietary fibre content. In addition, Landero et al. (2011) reported a linear reduction in diet nutrient digestibility values with increasing inclusion of canola meal, which was likely attributed to increased fibre content. Reduction of nutrient digestibility in diets with increased dietary fiber in this study was only apparent with the digestibility of CP, whereby diets containing ANC had reduced CP digestibility compared to the control. Woyengo et al. (2017) reported that plant-derived dietary protein sources contain anti-nutritional factors (ANFs) such as tannins, saponins, chelating agents, protease inhibitors, and phytohaemagglutintins. These ANFs interfere with nutrient digestion, absorption, and utilization (Akande et al., 2010). Since Amarula nut cake is a plant-derived protein source, it is likely to contain ANFs, which might have interfered with the digestibility of CP by the pigs in the present study. Poor CP digestibility could affect the efficiency with which feed are converted to weight gain. Thus, the poor feed conversion ratio (FCR) in pigs fed diets with increased levels of ANC could be related to ANFs that might be present in the ANC. Wang et al. (2016) demonstrated that high residual oil in diets negatively impacts nutrient digestion and absorption, which was apparent in this study with pigs fed diets that contained high levels of ANC. The higher fibre digestibility observed for pigs fed diets containing higher levels of ANC (Table 7) could have resulted from fermentation of the fibre in the hind gut with the volatile fatty acids (VFAs) produced, contributing to the net energy requirements of the pigs (Mwesigwa et al. 2013).

High fibre diets have been reported to increase total empty weight of the gastrointestinal tract and the volume of digesta in the gut, resulting in lower carcass DP (Smit and Beltranena, 2017). Since the ANC diets contained high fibre compared with the control, it was expected that pigs fed these diets would have carcasses with a low DP. However, the DP was not affected by the dietary treatments (Table 8). Feeding diets that contain high fibre might result in reduced carcass yield in pigs compared to those fed diets containing SBM, due to reduced dietary fibre (Ruckli and Bee, 2016). Consistently, the warm and cold carcasses of the pigs in the present study were reduced with diets that contained increased inclusion levels of ANC.

Back-fat thickness is usually affected by composition of the diet (Hernandez-Lopez et al., 2016). Apple et al. (2004) reported that higher dietary energy leads to increased back-fat thickness and reduced back fat depth reflects a reduction in lipid deposition brought by decreased energy intake. Smit and Beltranena (2017) reported a decreased back fat thickness in pig carcass when Camelina cake was increased in the diet of growing pigs, likely because of feed aversion that caused reduced fat deposition. In contrast, the back-fat thickness of the carcass in the present study was not affected by the dietary treatments. 
According to Kanengoni et al. (2014) drip loss in pork is affected by various and complex factors, which include, among other factors, the rate of $\mathrm{pH}$ decline and the ultimate $\mathrm{pH}$. The ultimate $\mathrm{pH}$ of the pig carcasses in the present study was similar across treatments; hence, the drip loss percentage was not affected.

Data on the effects of dietary ANC inclusion on meat colour is shown in Table 9. The redness (a*) value is related to the concentration of pigments and to the $\mathrm{pH}$ value, while the lightness $\left(\mathrm{L}^{*}\right)$ value is related to the moisture and fat contents of the carcass, and is also affected by the $\mathrm{pH}$ of the carcass. Increasing ANC in the diet improved both the redness and lightness of the meat, while the yellowness of the meat was not affected. The average values of the colour of the meat are consistent with the report of Temperan et al. (2014) who reported colour components ( $L^{*}$, $a^{*}$ and $b^{\star}$ ) in meat from pigs of different breeds to be in the ranges of 44-58,5-10 and 4-9, respectively.

\section{Conclusions}

This study showed that ANC could be used as a potential feedstuff in pig diets without causing any detrimental effects on the growth performance, nutrient digestibility and carcass traits of pigs. However, the ANC inclusion levels above $15 \%$ in pig diets increased FCR, thus reduced BWG in the pigs. As with reduced BWG, weights of cold and warm carcasses of pigs fed diets with ANC above $15 \%$ were reduced. It is therefore concluded that ANC can partially replace SBM in the diet of growing pigs at less than $15 \%$ inclusion level. Although the ANFs (in ANC) that could have negatively affected the pig weights were not assayed, further defatting of the cake in a form of chemical, solvent and or mechanical extraction could reduce not only the ANFs, but the residual oil of the cake for improved nutritional value prior to the cake being supplemented in pig diets. Expenditure amount of the extraction cost can be compensated by the cost of the extracted oil, which might also yield profit margins. Thus, further work to evaluate performance of pigs fed diets that contain defatted ANC should be done. Importantly, effects of the ANC oil fatty acids on the pig carcasses should be evaluated. In addition,

\section{Declarations}

\section{Acknowledgement}

This study is dedicated to the late Dr R.S Thomas, who played a significant role in the planning and execution of the study. Ms. Cynthia Ngwane is acknowledged for her assistance with statistical design and analysis.

\section{Author contribution}

PMM and BDN conceived and designed research. PMM, MMR and BDN conducted experiments and analysed data. PMM wrote the first version of the manuscript. BDN, IMM, MMR and TTN revised and edited the final version of the manuscript. All authors read and approved the manuscript.

\section{Funding information}

This work was supported by the National Research Foundation of South Africa (Grant No. 108992)

\section{Availability of data and materials}

Not applicable

\section{Code availability}


Not applicable

\section{Ethics approval}

This study was approved by the ARC-AP Animal Ethics Committee on Animal Use of the Institute under protocol No: APAEC (2019/17)

\section{Conflict of interest}

The authors declare that they have no conflict of interests.

\section{References}

1. Agyekum, A.K., Sands, J.S., Regassa, A., Kiarie, E., Weihrauch, D., et al. 2015. Effect of supplementing a fibrous diet with a xylanase and $\beta$-glucanase blend on growth performance, intestinal glocuse uptake, and transport associated gene expression in growing pigs. Journal of Animal Science, 93: 3483-3493.

2. Akande, K. E., Doma, U. D., Agu, H. O. and Adamu, H. M., 2010. Major anti-nutrients found in plant protein sources: their effect on nutrition. Pakistan Journal of Nutrition, 9: 827-832.

3. AOAC, 2003. Official Methods of Analysis of the Association of Official's Analytical Chemists, 17th edn. Association of Official Analytical Chemists, Arlington, Virginia.

4. Apple, J.K., Maxwell, C.V., Brown, D.C., Friesen, K.G., Musser, R.E., Johnson, Z.B., Armstrong, T.A., 2004. Effects of dietary lysine and energy density on performance and carcass characteristics of finishing pigs fed ractopamine. Journal of Animal Science, 82: 3277-3287.

5. Bonvillani, A., Peña, F., De Gea, G., Gómez, G., Petryna, A., et al. 2010. Carcass characteristics of Criollo Cordobés kid goats under an extensive management system: Effects of gender and live weight at slaughter. Meat Science, 86, 651-659.

6. Bruwer, G.G., Heinze, P.H., Zondagh, I.B., Naudé, R.T., 1991. The development of a new classification system for pig carcass in the Republic of South Africa. Porcus. 27-31.

7. Choi, H.B., Jeong, D.H. Kim, Y. Lee, Kwon, H., Kim, Y.Y., 2015. Influence of rapeseed meal on growth performance, blood profiles, nutrient digestibility and economic benefit of growing - finishing pigs. Asian-Australas. Journal of Animal Science, 28: 1345-1353.

8. Choi, Y. M. and Oh, H. K., 2016. Carcass performance, muscle fiber, meat quality, and sensory quality characteristics of crossbred pigs with different live weights. Korean Journal for Food Science of Animal Resources, 36: 389-396.

9. Cortamira, O., Gallego, A., Kim, S.W., 2000. Evaluation of twice-decorticated sunflower meal as a protein source compared with soybean meal in pig diets. Asian-Australasian Journal of Animal Science, 13: 1296-1303.

10. De la Llata, M., Dritz, S.S., Tokach, M.D., Goodband, R.D., Nelssen, J.L., Loughin, T.M., 2001. Effects of dietary fat on growth performance and carcass characteristics of growing-finishing pigs reared in a commercial environment. Journal of Animal Science, 79: 2643-2650.

11. Galassi, G., Colombini, S., Malagutti, L., Crovetto, G.M., Rapetti, L., 2010. Effects of high fiber and low protein diets on performance, digestibility, nitrogen excretion and ammonia emission in the heavy pig. Animal Feed Science and Technology, 134: 326-336.

12. Glass, G.V., Peckham, P.D. and Sanders, J.R., 1972. Consequences of failure to meet assumptions underlying the fixed effects analyses of variance and covariance. Review Education Research, 42: 237-288. 
13. Hernandez-Lopez, S.H., Rodriguez-Carpena, J.G., Lemus-Flores, C., Grageola-Nunez, F., Estevez, M., 2016. Avocado waste for finishing pigs: impact on muscle composition and oxidative stability during chilled storage. Meat Science, 116: 186-192.

14. Kanengoni, A.T., Chimonyo, M., Erlwanger, K.H., Ndimba, B.K., Dzama, K., 2014. Growth performance, blood metabolic responses, and carcass characteristics of grower and finisher South African Windsnyer-type indigenous and Large White $x$ Landrace crossbred pigs fed diets containing ensiled corncobs. Journal of Animal Science, 92: 5739-5748.

15. Krzywicki, K., 1979. Assessment of relative content of myoglobin, oxymyoglobin and metmyoglobin at the surface of beef. Meat Science, 3: 1-10.

16. Landero, J. L., Beltranena, E., Cervantes, M., Morales, A., Zijlstra, R.T., 2011. The effect of feeding solventextracted canola meal on growth performance and diet nutrient digestibility in weaned pigs. Animal Feed Science and Technology, 170: 136-140.

17. Len, N.T., Lindberg, J.E. and Ogle, B., 2008. Effect of dietary fibre level on the performance and carcass traits of Mong Cai F1 crossbred (Mong Cai x Yorkshire) and landrace x Yorkshire pigs. Asian-Australasian Journal of Animal Science, 21: 245-251.

18. Liu, H., Chen, Y., Li, Z., Lai, C., Piao, X., et al. 2019. Metabolizable energy requirement for maintenance estimated by regression analysis of body weight gain or metabolizable energy intake in growing pigs. Asian-Australas. Journal of Animal Science, 32: 1397-1406.

19. Malebana, I. M., Nkosi, B. D., Erlwanger, K. H. and Chivandi, E., 2018. A comparison of the proximate, fibre, mineral content, amino acid and the fatty acid profile of Marula (Sclerocarya birrea caffra) nut and soyabean (Glycine max) meals. Journal of the Science of Food and Agriculture, 98, 1381-1387.

20. Mazizi, B.E., Erlwanger, K.H., Chivandi, E., 2020. The effect of dietary marula nut meal on the physiological properties, proximate and fatty acid content of Japanese quail meat. Veterinary Animal Science, 9: 100096.

21. McDonald P, Edwards, RA, Greenhalgh JFD, Morgan CA, Sinclair LA, Wilkinson RG. Animal Nutrition. 7th ed. Pearson Prentice Hall; 2010.

22. McDonald, P., Edward, R.A., Greenhalgh, J.F.D., Morgan, C.A., Sinclair, L.A., Wilkinson, R.G., 2011. Animal. 7th Ed. Prentice Hall/Pearson Education Ltd., Harlow, UK, ISBN-13:9781408204238\$4 Pages: 692.

23. Mdziniso, P.M., Dlamini, A.M., Khumalo, G.Z., Mupangwa, J.F., 2016. Nutritional evaluation of marula (Sclerocarya birrea) seed cake as a protein supplement in dairy meal. Journal of Applied Life Sciences International, 4: 1-11.

24. Mlambo, V., Dlamini, B.J., Nkambule, M.T., Mhazo, N., Sikosana J.L.N., 2011. Nutritional evaluation of marula (Sclerocarya birrea) seed cake as a protein supplement for goats fed grass hay. Tropical Agriculture Journal (Trinidad), 88: 35-43.

25. Moughan, P. J., Smith, W. C., Schrama, J. and Smits, C., 1991. Chromic oxide and acid-insoluble ash as faecal markers in digestibility studies with young growing pigs. New Zealand Journal of Agricultural Research, 34: 85-88.

26. Mozaffarian, D., 2008. Fish and n-3 fatty acids for the prevention of fatal coronary heart disease and sudden cardiac death. Animal Journal Clinical Nutrition, 87: 1991S-1996S.

27. Mthiyane, M.N.M., Mhlanga, B.S., 2017. The nutritive value of marula (Sclerocarya birrea) seed cake for broiler chickens: nutritional composition, performance, carcass characteristics and oxidative and mycotoxin status. Tropical Animal Health Production, 49: 835-842. 
28. Mwesigwa, R., Mutetikka, D., Kugonza, D.R., 2013. Performance of growing pigs fed diets based on by-products of maize and wheat processing. Tropical Animal Health Production, 45: 441-446.

29. National Research Council (NRC), 1998. Nutrient requirements of swine. 10th (eds). National Academy Press, Washington, D.C, pp. 1-420.

30. National Research Council (NRC), 2001. Nutrient requirements of dairy cattle, 7th (eds). National Academies Press, Washington D.C, pp. 1-347.

31. Nkosi, B. D., Phenya, J. S. M., Malebana, I. M. M., Muya, M. C. and Motiang, M. D., 2019. Nutrient evaluation and ruminal degradation of dry matter and protein from amarula (Sclerocarya birrea), macadamia (integrifolia) and baobab (Adansonia digitata L.) oilcakes as dietary supplements for ruminants. Tropical animal health and production, 51:1981-1988.

32. Payne, W.J.A., 1990. An introduction to animal husbandry in the tropics. 4th Ed., ELBS, Longman, Singapore. pp 627-683.

33. Pekel, A. Y., Kim, J. I., Chapple, C. and Adeola. O., 2015. Nutritional characteristics of Camelina meal for 3-weekold broiler chickens. Poultry Science, 94:371-378.

34. Ruckli, A. and Bee, G., 2016. Moringa oleifera as an alternative protein source to soybean meal in pig production. Journal of Animal Science, 94: 60 (Suppl 2).

35. SAS Institute Inc. 2016. SAS® 9.4 Language Reference: Concepts, Sixth Edition. Cary, NC: SAS Institute Inc.

36. Shapiro, S. S. and Wilk, M. B., 1965. An Analysis of Variance Test for Normality (complete samples). Biometrika, 52: 591-611.

37. Sihlobo, W., Kapuya, T., 2016. South Africa's soybean industry: A brief overview. Grain SA. .

38. Smit, M.N. and Beltranena, E., 2017. Increasing dietary inclusion of camelina cake fed to pigs from weaning to slaughter: safety, growth performance, carcass traits, and n-3 enrichment of pork. Journal of Animal Science, 95: 2952-2967.

39. Snedecor, G.W. and Cochran, W.G., 1980. Statistical methods (7th Ed.). Ames: lowa State University Press, pp 507.

40. Stephenson, E.W., Vaughan, M.A., Burnett, D.D., Paulk, C.B., Tokach, M.D., et al. 2016. Influence of dietary fat source and feeding duration on finishing pig growth performance, carcass composition, and fat quality. Journal of Animal Science, 94: 2851-2866.

41. Temperan, S., Lorenzo, J.M., Castineiras, B.D., Franco, I., Carballo, J., 2014. Carcass and meat quality traits of Celta heavy pigs: effects of inclusion of chestnuts in the finishing diet. Spanish Journal of Agriculture Research, 12: 694-707.

42. Thacker, P.A. and Campbell, G.L., 1999. Performance of growing/finishing pigs fed untreated or micronized hulless barley-based diets with or without ß-glucanase. Journal of Animal Feed Science, 8: 157-170.

43. Wang, Y., Dellatore, P., Douard, V., Qin, L., Watford, M., Ferraris, R.P., Lin, T., Shapses, S.A., 2016. High fat diet enriched with saturated, but not monounsaturated fatty acids adversely affects femur, and both diets increase calcium absorption in older female mice. Nutrition Research, 11: 742-750.

44. Woyengo, T. A., Beltranena, E., Zijlstra, R. T., 2017. Effect of anti-nutritional factors of oilseed co-products on feed intake of pigs and poultry. Animal Feed Science and Technology, 233: 76-86.

\section{Tables}


Table 1

Nutrients and mineral composition of amarula nut meal $(n=3)$

\begin{tabular}{|c|c|c|}
\hline Parameters & ANC & SD \\
\hline \multicolumn{3}{|l|}{ Nutrients composition } \\
\hline DM (g/kg DM) & 963.5 & 0.04 \\
\hline Ash (g/kg DM) & 48.5 & 0.11 \\
\hline CP (g/kg DM) & 322.9 & 0.05 \\
\hline $\mathrm{EE}(\mathrm{g} / \mathrm{kg} \mathrm{DM})$ & 343.9 & 0.09 \\
\hline GE (g/kg DM) & 25.3 & 0.01 \\
\hline NDF (g/kg DM) & 244.0 & 0.46 \\
\hline ADF (g/kg DM) & 223.2 & 0.10 \\
\hline ADL (g/kg DM) & 98.1 & 0.69 \\
\hline \multicolumn{3}{|l|}{ Mineral composition } \\
\hline Calcium (g/kg) & 1.8 & 0.06 \\
\hline Magnesium (g/kg) & 5.7 & 0.12 \\
\hline Phosphorus (g/kg) & 9.4 & 0.24 \\
\hline Potassium (g/kg) & 8.3 & 0.21 \\
\hline Sodium (mg/kg) & 345.7 & 223.9 \\
\hline Iron (mg/kg) & 95.5 & 13.3 \\
\hline Copper (mg/kg) & 27.9 & 1.05 \\
\hline Manganese (mg/kg) & 10.2 & 0.43 \\
\hline Zinc (mg/kg) & 60.2 & 1.30 \\
\hline Cobalt (mg/kg) & 0.14 & 0.04 \\
\hline Molybdenum (mg/kg) & 0.31 & 0.01 \\
\hline
\end{tabular}


Table 2

Amino acid composition of amarula nut cake $(n=3)$

\begin{tabular}{|lll|}
\hline & g/kg & SD \\
\hline Essential amino acids & & \\
\hline Arginine & 50.5 & 0.04 \\
\hline Histidine & 6.1 & 0.01 \\
\hline Isoleucine & 12.9 & 0.01 \\
\hline Leucine & 12.3 & 0.01 \\
\hline Lysine & 6.8 & 0.02 \\
\hline Methionine & 4.4 & 0.01 \\
\hline Phenylalanine & 12.8 & 0.01 \\
\hline Threonine & 8.1 & 0.03 \\
\hline Tryptophan & 4.4 & 0.01 \\
\hline Valine & 15.6 & 0.03 \\
\hline Non-essential amino acids & & \\
\hline Alanine & 10.4 & 0.04 \\
\hline Aspartic acid & 27.4 & 0.01 \\
\hline Glutamic acid & 84.0 & 0.01 \\
\hline Glycine & 18.0 & 0.01 \\
\hline Hydroxy-proline & 0.9 & 0.01 \\
\hline Proline & 11.3 & 0.02 \\
\hline Serine & 16.5 & 2.72 \\
\hline Tyrosine & & 0.01 \\
\hline ANC = Amarula nut cake; SD & & \\
\hline
\end{tabular}


Table 3

Experimental diets with varying inclusion levels of amarula nut cake

\begin{tabular}{|c|c|c|c|c|c|}
\hline \multirow[t]{2}{*}{ Ingredient (\%) } & \multicolumn{5}{|c|}{ Treatment } \\
\hline & Control & $5 \%$ & $10 \%$ & $15 \%$ & $20 \%$ \\
\hline Maize & 54.51 & 69.47 & 69.75 & 63.60 & 60.98 \\
\hline Sunflower oil cake & 15 & - & - & - & - \\
\hline Wheat bran & 15 & 18.24 & 15.57 & 16.84 & 14.79 \\
\hline Sunflower Oil & 2.64 & - & - & - & - \\
\hline Monocalcium & 0.89 & 1.45 & 1.29 & 0.99 & 0.83 \\
\hline Feed lime & 1.24 & 0.96 & 1.09 & 1.29 & 1.97 \\
\hline Lysine & 1.70 & 4.65 & 2.10 & 2.06 & 1.23 \\
\hline ANC & - & 5 & 10 & 15 & 20 \\
\hline Soybean oil cake & 8.82 & - & - & - & - \\
\hline aPremix & 0.20 & 0.20 & 0.20 & 0.20 & 0.20 \\
\hline \multicolumn{6}{|c|}{$\mathrm{ANC}=$ Amarula nut cake; $\mathrm{DM}=$ dry matter; $\mathrm{CP}=$ crude protein; $\mathrm{CF}=$ crude fibre; $\mathrm{DE}=$ digestible energy. } \\
\hline $\begin{array}{l}\text { aProvided the follo } \\
\text { vitamin } \mathrm{K}_{3}, 1-5 \mathrm{mg} \\
\text { calcium pantothen } \\
\mathrm{mg} \text { copper, } 1 \mathrm{mg} \text { io }\end{array}$ & $\begin{array}{l}\mathrm{nme} \text { of } \mathrm{di} \\
\mathrm{mg} \text { vitam } \\
\text { oline, } 0.6 \\
\text { rous, and }\end{array}$ & $\begin{array}{l}\text { IU vitan } \\
3 \mathrm{mg} \mathrm{v} \\
\text { acid, } 0 . \\
\text { eleniun }\end{array}$ & $\begin{array}{l}200 \mathrm{IU} \text { vi } \\
\mathrm{B}_{12}, 2.5 \mathrm{r} \\
\text { biotin, } 4 \mathrm{C}\end{array}$ & $\begin{array}{l}D_{3}, 40 \mathrm{IU} \\
\text { min } B 6,2 \\
\text { anganes }\end{array}$ & $\begin{array}{l}n \mathrm{E}, 2 \mathrm{mg} \\
\text { iacin, } 12 \mathrm{~m} \\
\mathrm{mg} \text { zinc, } 1\end{array}$ \\
\hline
\end{tabular}


Table 4

Nutrient and mineral profile of experimental diets containing amarula nut cake at varying levels $(n=3)$

Parameters Treatment

$P$-value

Control $5 \% \quad 10 \% \quad 15 \% \quad 20 \% \quad$ SEM $\quad$ Treatment Linear $\quad$ Quadratic

\section{Nutrient composition}

\begin{tabular}{|c|c|c|c|c|c|c|c|c|c|}
\hline DM (g/kg) & $956.8^{b}$ & $958.9^{a}$ & $954.4^{c}$ & $953.8^{c}$ & $956.3^{b}$ & 0.19 & $<.0001$ & -0.039 & 0.001 \\
\hline Ash (g/kg) & 51.2 & 50.1 & 47.7 & 47.0 & 48.8 & 0.20 & 0.0687 & $-0.058 * \star$ & $0.002^{\star}$ \\
\hline $\mathrm{CP}(\mathrm{g} / \mathrm{kg})$ & $171.0^{a}$ & $164.6^{b}$ & $162.8^{b}$ & $149.8^{c}$ & $145.2^{d}$ & 1.01 & $<.0001$ & $-0.088^{* * *}$ & -0.00 \\
\hline EE (g/kg) & $44.4^{\mathrm{e}}$ & $56.0^{d}$ & $72.4^{\mathrm{C}}$ & $78.1^{\mathrm{b}}$ & $96.8^{a}$ & 1.88 & $<.0001$ & $0.235^{\star \star \star}$ & 0.001 \\
\hline $\begin{array}{l}\text { GE (MJ/kg } \\
\text { DM) }\end{array}$ & $17.6^{c}$ & $17.7^{c}$ & $17.8^{\mathrm{bc}}$ & $18.1^{\mathrm{b}}$ & $18.5^{a}$ & 0.37 & 0.0006 & $-0.015^{\star \star \star}$ & $0.003^{\star \star}$ \\
\hline NDF $(\mathrm{g} / \mathrm{kg})$ & $313.4^{b}$ & $291.8^{c}$ & $295.1^{c}$ & $337.5^{a}$ & $337.1^{a}$ & 2.05 & $<.0001$ & $-0.280 * \star *$ & $0.02^{\star \star}$ \\
\hline ADF (g/kg) & $88.7^{b c}$ & $83.6^{c}$ & $85.8^{c}$ & $95.4^{b}$ & $103.8^{a}$ & 0.82 & 0.0003 & $-0.114 * \star \star$ & $0.010 * * \star$ \\
\hline ADL $(\mathrm{g} / \mathrm{kg})$ & $14.1^{\mathrm{C}}$ & $19.1^{\mathrm{b}}$ & $23.3^{a}$ & $26.4^{a}$ & $24.9^{a}$ & 0.50 & 0.0003 & $0.138 * \star \star$ & $-0.004 * *$ \\
\hline
\end{tabular}

\section{Mineral profile}

\begin{tabular}{|c|c|c|c|c|c|c|c|c|c|}
\hline $\begin{array}{l}\text { Calcium } \\
(\mathrm{g} / \mathrm{kg})\end{array}$ & $7.1^{\mathrm{b}}$ & $7.9^{a}$ & $8.3^{a}$ & $8.3^{a}$ & $8.2^{\mathrm{a}}$ & 0.55 & $<.0001$ & $0.19 * \star \star$ & $-0.01 * \star \star$ \\
\hline $\begin{array}{l}\text { Magnesium } \\
(\mathrm{g} / \mathrm{kg})\end{array}$ & $2.4^{\mathrm{a}}$ & $2.2^{b}$ & $2.1^{b c}$ & $2.1^{b c}$ & $2.0^{c}$ & 0.13 & $<.0001$ & $-0.03^{\star \star \star}$ & $0.001 *$ \\
\hline $\begin{array}{l}\text { Phosphorus } \\
(\mathrm{g} / \mathrm{kg})\end{array}$ & $6.3^{a}$ & $5.5^{\mathrm{b}}$ & $5.5^{\mathrm{b}}$ & $5.5^{\mathrm{b}}$ & $5.1^{c}$ & 0.42 & $<.0001$ & $-0.09 * \star \star$ & 0.002 \\
\hline $\begin{array}{l}\text { Potassium } \\
(\mathrm{g} / \mathrm{kg})\end{array}$ & $7.90^{a}$ & $6.6^{b}$ & $6.2^{c}$ & $5.8^{d}$ & $5.1^{\mathrm{e}}$ & 0.95 & $<.0001$ & $-0.21^{\star \star \star}$ & $0.004^{\star * *}$ \\
\hline $\begin{array}{l}\text { Sodium } \\
\text { (mg/kg) }\end{array}$ & 243.2 & 255.4 & 239.8 & 233.8 & 227.3 & 24.4 & 0.6023 & 0.52 & -0.08 \\
\hline Iron (mg/kg) & 161.5 & 169.8 & 149.5 & 143.3 & 135.5 & 23.8 & 0.2566 & $-0.54^{\star}$ & -0.05 \\
\hline $\begin{array}{l}\text { Copper } \\
\text { (mg/kg) }\end{array}$ & 73.3 & 58.4 & 58.2 & 60.2 & 59.8 & 8.6 & 0.0416 & $-2.29 *$ & $0.09 *$ \\
\hline $\begin{array}{l}\text { Manganese } \\
(\mathrm{mg} / \mathrm{kg})\end{array}$ & $84.9^{a}$ & $73.8^{b}$ & $70.2^{b}$ & $84.6^{a}$ & $63.0^{c}$ & 9.4 & $<.0001$ & $-0.49 *$ & -0.01 \\
\hline Zinc (mg/kg) & $48.5^{\mathrm{a}}$ & $44.8^{b}$ & $45.0^{b}$ & $42.2^{b}$ & $38.7^{c}$ & 3.7 & $<.0001$ & $-0.3 * \star \star$ & -0.01 \\
\hline $\begin{array}{l}\text { Cobalt } \\
(\mathrm{mg} / \mathrm{kg})\end{array}$ & $0.30^{\mathrm{a}}$ & $0.26^{a b}$ & $0.28^{\mathrm{ab}}$ & $0.29^{a}$ & $0.23^{b}$ & 0.03 & 0.0230 & $0.0003^{*}$ & -0.0001 \\
\hline
\end{tabular}

\footnotetext{
a-d Values with different superscripts within a row are different; SEM = standard error mean; Level of significance $\left({ }^{*} \mathrm{P}<0.05 ; * * \mathrm{P}<0.01 ; * \star *=\mathrm{P}<0.001\right)$; control = no amarula nut meal; $\mathrm{ADF}=$ acid detergent fibre; $\mathrm{ADL}$ = acid detergent lignin; $\mathrm{CP}$ = crude protein; $\mathrm{DM}$ = dry matter; $\mathrm{EE}$ = ether extract; $\mathrm{GE}$ = gross energy; NDF - neutral detergent fibre.
} 


\begin{tabular}{|c|c|c|c|c|c|c|c|c|c|}
\hline \multirow[t]{2}{*}{ Parameters } & \multicolumn{6}{|c|}{ Treatment } & \multicolumn{3}{|l|}{$P$-value } \\
\hline & Control & $5 \%$ & $10 \%$ & $15 \%$ & $20 \%$ & SEM & Treatment & Linear & Quadratic \\
\hline $\begin{array}{l}\text { Molybdenum } \\
(\mathrm{mg} / \mathrm{kg})\end{array}$ & $0.45^{\mathrm{a}}$ & $0.35^{b}$ & $0.31^{c}$ & $0.26^{d}$ & $0.21^{e}$ & 0.08 & $<.0001$ & $-0.02 * \star \star$ & $0.0003 * \star$ \\
\hline
\end{tabular}


Table 5

Amino acid composition of the experimental diets containing varying levels of amarula nut cake $(n=3)$

Amino acid $(\mathrm{g} / \mathrm{kg})$

Treatment

Pvalue

Control $5 \% \quad 10 \% \quad 15 \% \quad 20 \% \quad$ SEM $\quad$ Treatment Linear Quadratic

\section{Essential amino acids}

\begin{tabular}{|c|c|c|c|c|c|c|c|c|c|}
\hline Arginine & $13.4^{\mathrm{b}}$ & $13.4^{b}$ & $14.0^{\mathrm{ab}}$ & $13.7^{b}$ & $14.3^{\mathrm{a}}$ & 0.17 & 0.0004 & $0.002^{\star *}$ & NS \\
\hline Histidine & $4.9^{b}$ & $5.2^{\mathrm{a}}$ & $5.0^{a b}$ & $4.4^{\mathrm{c}}$ & $3.4^{\mathrm{d}}$ & 0.05 & $<.0001$ & $0.01^{\star \star *}$ & $-0.001 * \star \star$ \\
\hline Isoleucine & 6.4 & 6.2 & 4.7 & 5.3 & 5.1 & 0.54 & 0.284 & NS & NS \\
\hline Leucine & $12.3^{a}$ & $12.4^{a}$ & $12.0^{\mathrm{a}}$ & $11.6^{b}$ & $10.7^{b}$ & 0.19 & 0.0011 & $0.003^{\star \star \star}$ & -0.001 ** \\
\hline Lysine & $22.3^{a}$ & $20.6^{b}$ & $18.6^{c}$ & $15.1^{\mathrm{e}}$ & $17.8^{d}$ & 0.15 & $<.0001$ & $-0.07 * \star \star *$ & $0.002^{\star *}$ \\
\hline Methionine & 2.5 & 2.6 & 2.5 & 2.5 & 2.2 & 0.11 & 0.174 & $0.003^{*}$ & NS \\
\hline Phenylalanine & $7.0^{\mathrm{a}}$ & $7.1^{a}$ & $6.8^{a}$ & $6.1^{\mathrm{b}}$ & $6.0^{\mathrm{b}}$ & 0.024 & 0.0272 & -0.001 ** & NS \\
\hline Threonine & $6.2^{a}$ & $5.6^{b}$ & $5.3^{c}$ & $4.9^{d}$ & $4.3^{\mathrm{e}}$ & 0.007 & $<.0001$ & $-0.01 * \star \star$ & NS \\
\hline Tryptophan & 2.3 & 2.2 & 2.2 & 8.5 & 4.9 & 0.190 & 0.2143 & NS & NS \\
\hline Valine & $7.9^{a}$ & $7.4^{\mathrm{a}}$ & $7.4^{\mathrm{a}}$ & $6.7^{\mathrm{b}}$ & $6.5^{\mathrm{b}}$ & 0.015 & 0.0004 & $-0.01 * * *$ & NS \\
\hline
\end{tabular}

\section{Non-essential amino acids}

\begin{tabular}{|c|c|c|c|c|c|c|c|c|c|}
\hline Alanine & $0.75^{\mathrm{a}}$ & $0.73^{b}$ & $0.71^{\mathrm{c}}$ & $0.68^{d}$ & $0.63^{e}$ & 0.010 & $<.0001$ & $-0.002^{\star \star \star *}$ & $-0.0002^{\star \star *}$ \\
\hline Aspartic acid & $1.43^{\mathrm{a}}$ & $1.29^{b}$ & $1.19^{c}$ & $1.08^{d}$ & $0.98^{e}$ & 0.004 & $<.0001$ & $-0.03^{\star \star \star}$ & $0.0002^{\star \star}$ \\
\hline Glutamic acid & $3.04^{\mathrm{a}}$ & $2.92^{c}$ & $2.95^{\mathrm{b}}$ & $2.93^{c}$ & $2.80^{d}$ & 0.004 & $<.0001$ & $-0.01 * \star \star *$ & NS \\
\hline Glycine & $0.86^{a}$ & $0.77^{b}$ & $0.77^{b}$ & $0.71^{c}$ & $0.67^{d}$ & 0.003 & $<.0001$ & $-0.01 * \star \star$ & NS \\
\hline Ho-proline & $0.05^{c}$ & $0.06^{b}$ & $0.07^{a}$ & $0.04^{d}$ & $0.04^{d}$ & 0.002 & $<.0001$ & $0.002^{\star \star}$ & $-0.0002^{\star *}$ \\
\hline Proline & $0.94^{\mathrm{a}}$ & $0.90^{b}$ & $0.88^{b}$ & $0.88^{b}$ & $0.83^{c}$ & 0.008 & $<.0001$ & $-0.004^{\star \star *}$ & NS \\
\hline Serine & $0.83^{a}$ & $0.77^{b}$ & $0.75^{c}$ & $0.70^{d}$ & $0.66^{\mathrm{e}}$ & 0.003 & $<.0001$ & $-0.01 * * \star$ & NS \\
\hline Tyrosine & $0.50^{a}$ & $0.62^{b}$ & $0.67^{a}$ & $0.51^{a}$ & $0.44^{\mathrm{d}}$ & 0.006 & $<.0001$ & $0.03^{* \star}$ & $-0.002^{* * *}$ \\
\hline
\end{tabular}

a - d Values with different superscripts within a row are different; SEM = standard error mean; Level of significance $\left({ }^{*} \mathrm{P}<0.05 ;{ }^{* *} \mathrm{P}<0.01 ;{ }^{* \star *}=\mathrm{P}<0.001\right)$; control = no amarula nut cake; NS = not significant. 
Table 6

Effects of varying dietary inclusion levels of amarula nut cake on growth performance of pigs $(n=8)$

\begin{tabular}{|c|c|c|c|c|c|c|c|c|c|}
\hline \multirow[t]{2}{*}{ Parameters } & \multicolumn{6}{|c|}{ Treatment } & \multicolumn{3}{|l|}{$P$-value } \\
\hline & Control & $5 \%$ & $10 \%$ & $15 \%$ & $20 \%$ & SEM & Treatment & Linear & Quadratic \\
\hline IBW (kg) & 21.93 & 21.40 & 21.98 & 21.63 & 21.83 & 0.46 & 0.89 & NS & NS \\
\hline FBW (kg) & $62.30^{\mathrm{a}}$ & $65.28^{a}$ & $61.40^{\mathrm{a}}$ & $50.98^{b}$ & $54.77^{b}$ & 1.74 & $<.0001$ & $-0.31 \star \star$ & NS \\
\hline BWG (kg) & $40.37^{a}$ & $43.88^{a}$ & $39.42^{a}$ & $29.35^{b}$ & $32.93^{b}$ & 1.67 & $<.0001$ & -0.28 ** & NS \\
\hline ADG (kg) & $0.64^{a}$ & $0.70^{a}$ & $0.63^{a}$ & $0.47^{b}$ & $0.52^{b}$ & 0.026 & $<.0001$ & $-0.004^{\star \star}$ & NS \\
\hline ADFI (kg) & 1.71 & 1.67 & 1.54 & 1.50 & 1.58 & 0.073 & 0.23 & NS & NS \\
\hline FCR & $2.70^{a b c}$ & $2.41^{\mathrm{c}}$ & $2.50^{\mathrm{bc}}$ & $3.25^{\mathrm{a}}$ & $3.04^{\mathrm{ab}}$ & 0.16 & 0.004 & $-0.017 * \star$ & NS \\
\hline
\end{tabular}

a - c Values with different superscripts within a row are different, $* P<0.05 ; * \star P<0.01 ; * \star * P<0.001$; NS = not significant; $A N C=$ Amarula nut cake; IBW = Initial body weight; FBW = Final body weight; $B W G=$ Body weight gain; $A D G$ = Average daily gain; $A D F I=$ Average daily feed intake; FCR = Feed conversion rate.

Table 7

Effects of varying dietary inclusion levels of amarula nut cake on nutrient digestibility by pigs $(n=8)$

\begin{tabular}{|c|c|c|c|c|c|c|c|c|c|}
\hline \multirow[t]{2}{*}{ Parameters (\%) } & \multicolumn{6}{|c|}{ Treatment } & \multicolumn{3}{|l|}{$P$-value } \\
\hline & control & $5 \%$ & $10 \%$ & $15 \%$ & $20 \%$ & SEM & Treatment & Linear & Quadratic \\
\hline DM & 92.4 & 86.4 & 87.0 & 88.3 & 91.9 & 2.61 & 0.3765 & -1.07 & $0.05^{\star}$ \\
\hline $\mathrm{CP}$ & $86.4^{a}$ & $85.9^{a}$ & $81.6^{b}$ & $80.2^{b c}$ & $79.4^{c}$ & 0.54 & $<.0001$ & $-0.33^{\star \star \star}$ & $0.03^{\star \star}$ \\
\hline EE & $67.5^{\mathrm{b}}$ & $67.8^{b}$ & $69.7^{b}$ & $76.8^{a b}$ & $79.7^{a}$ & 2.51 & 0.005 & $-0.01 * \star \star$ & 0.03 \\
\hline aNDF & $58.9^{c}$ & $61.6^{c}$ & $64.2^{b c}$ & $68.6^{a b}$ & $71.5^{a}$ & 1.81 & 0.001 & $0.50 * * \star$ & 0.01 \\
\hline ADF & $49.3^{c}$ & $54.8^{b}$ & $57.3^{\mathrm{ab}}$ & $62.4^{\mathrm{a}}$ & $60.1^{a b}$ & 1.50 & 0.0002 & $1.27^{\star \star \star}$ & $-0.04^{\star}$ \\
\hline ADL & $46.6^{d}$ & $53.6^{c}$ & $58.4^{\mathrm{b}}$ & $62.1^{\mathrm{a}}$ & $63.1^{a}$ & 1.15 & $<.0001$ & $1.56^{\star \star \star}$ & $-0.04^{\star \star}$ \\
\hline Hemi & 68.1 & 72.2 & 73.4 & 74.7 & 75.3 & 2.41 & 0.3872 & $0.72^{*}$ & -0.02 \\
\hline
\end{tabular}


Table 8

Effects of varying dietary inclusion levels of amarula nut cake on carcass characteristics of pigs $(n=8)$

\begin{tabular}{|c|c|c|c|c|c|c|c|c|c|}
\hline \multirow[t]{2}{*}{ Parameters } & \multicolumn{6}{|c|}{ Treatment } & \multicolumn{3}{|l|}{$P$ value } \\
\hline & Control & $5 \%$ & $10 \%$ & $15 \%$ & $20 \%$ & SD & Treatment & Linear & Quadratic \\
\hline WCW (kg) & $50.37^{a}$ & $50.32^{a}$ & $47.67^{a}$ & $42.45^{b}$ & $42.23^{b}$ & 2.24 & 0.028 & $-0.32^{\star *}$ & -0.008 \\
\hline CCW (kg) & $48.97^{a}$ & $48.97^{a}$ & $46.42^{a}$ & $41.23^{b}$ & $40.97^{b}$ & 2.20 & 0.027 & $-0.29 * \star$ & -0.009 \\
\hline $\mathrm{BF}(\mathrm{mm})$ & 16.50 & 14.17 & 14.67 & 15.17 & 15.50 & 1.43 & 0.820 & -0.32 & 0.015 \\
\hline Dressing \% & 68.17 & 69.17 & 69.17 & 68.17 & 68.50 & 0.42 & 0.254 & 0.13 & -0.007 \\
\hline $\mathrm{CL}(\mathrm{cm})$ & 46.00 & 43.00 & 45.00 & 44.33 & 44.83 & 0.66 & 0.052 & -0.27 & 0.012 \\
\hline $\mathrm{HQL}(\mathrm{cm})$ & $14.00^{a}$ & $12.33^{b}$ & $13.67^{a b}$ & $14.17^{a}$ & $13.67^{a b}$ & 0.39 & 0.029 & -0.06 & 0.004 \\
\hline HQW (kg) & $23.33^{a}$ & $19.50^{\mathrm{b}}$ & $22.83^{a}$ & $20.83^{a b}$ & $23.00^{a}$ & 0.80 & 0.009 & -0.37 & 0.019 \\
\hline RW (kg) & 2.64 & 1.97 & 2.10 & 2.25 & 2.20 & 0.185 & 0.154 & -0.08 & 0.004 \\
\hline $\begin{array}{l}\text { Warm } \\
\text { muscle } \mathrm{pH}_{\mathrm{i}}\end{array}$ & 6.48 & 5.95 & 6.16 & 5.93 & 5.99 & 0.15 & 0.092 & $-0.06^{\star}$ & 0.02 \\
\hline $\begin{array}{l}\text { Cold } \\
\text { muscle } \\
\mathrm{pH}_{\mathrm{u}}\end{array}$ & 4.75 & 4.81 & 4.88 & 4.62 & 4.72 & 0.10 & 0.488 & 0.009 & -0.0007 \\
\hline $\begin{array}{l}\text { Temp } 45 \\
\text { min }\end{array}$ & 32.73 & 32.80 & 32.28 & 33.15 & 33.70 & 1.43 & 0.996 & -0.01 & 0.001 \\
\hline Temp 24hr & 8.53 & 8.80 & 8.45 & 9.82 & 9.28 & 0.58 & 0.449 & 0.04 & -0.0003 \\
\hline $\begin{array}{l}\text { Drip loss } \\
(\%)\end{array}$ & 6.06 & 4.31 & 4.75 & 4.73 & 4.85 & 0.61 & 0.348 & -0.22 & 0.009 \\
\hline WHC Ratio & 0.41 & 0.31 & 0.33 & 0.29 & 0.28 & 0.05 & 0.502 & -0.01 & 0.0003 \\
\hline $\begin{array}{l}\text { Eye Muscle } \\
\text { Area }\end{array}$ & 2548.8 & 2529.0 & 2677.3 & 2375.3 & 2276.2 & 166.2 & 0.483 & 20.82 & -1.74 \\
\hline $\begin{array}{l}\mathrm{a}-\text { b Values w } \\
\mathrm{P}<0.001) ; \mathrm{W} \\
\text { Hindquarter I } \\
45 \mathrm{~min}, \mathrm{pH}_{\mathrm{u}}=\end{array}$ & $\begin{array}{l}\text { differer } \\
W=\text { Warr } \\
\text { igth, HQ } \\
\text { Itimate }\end{array}$ & $\begin{array}{l}\text { superscr } \\
\text { carcass, } \\
=\text { Hindqu } \\
\text { at } 24 \mathrm{~h} \text {. }\end{array}$ & $\begin{array}{l}\text { ts within } \\
\mathrm{CW}=\text { Colc } \\
\text { rter weigh }\end{array}$ & $\begin{array}{l}\text { row are di } \\
\text { carcass, B } \\
\text { RW = Rib }\end{array}$ & $\begin{array}{l}\text { ferent; Le } \\
=\text { Back fa } \\
\text { veight, Wr }\end{array}$ & $\begin{array}{l}\text { of sig } \\
\text { thickne } \\
=\text { wate }\end{array}$ & $\begin{array}{l}\text { ficance }\left({ }^{*} \mathrm{P}<\right. \\
\mathrm{S}, \mathrm{CL}=\text { carcas } \\
\text { holding capa }\end{array}$ & $\begin{array}{l}.05 ; * \star P \\
\text { s length, } \\
\text { city, } \mathrm{pH}_{\mathrm{i}}=\end{array}$ & $\begin{array}{l}0.01 ; * * *= \\
\text { QL }= \\
\text { nitial pH at }\end{array}$ \\
\hline
\end{tabular}


Table 9

Effect of varying dietary inclusion levels of amarula nut cake on meat colour of pig carcasses $(n=3)$

\begin{tabular}{|c|c|c|c|c|c|c|c|c|c|}
\hline \multirow[t]{2}{*}{ Parameters } & \multicolumn{6}{|c|}{ Treatments } & \multicolumn{3}{|l|}{$P$-value } \\
\hline & Control & $5 \%$ & $10 \%$ & $15 \%$ & $20 \%$ & SEM & Treatment & Linear & Quadratic \\
\hline$L^{*}$ & $49.9^{b}$ & $49.7^{b}$ & $49.9^{b}$ & $52.9^{a}$ & $51.9^{a}$ & 0.650 & 0.004 & 0.001 & 0.647 \\
\hline$a^{*}$ & 3.13 & 2.69 & 2.37 & 3.18 & 2.77 & 0.285 & 0.270 & 0.812 & 0.271 \\
\hline$b^{*}$ & $12.44^{\mathrm{bc}}$ & $12.11^{\mathrm{c}}$ & $11.83^{c}$ & $13.13^{a}$ & $13.06^{a b}$ & 0.219 & 0.001 & 0.003 & 0.017 \\
\hline
\end{tabular}

a - c Values with different superscripts within a row are different, $L^{*}=$ lightness; $a^{*}=$ redness; $b^{\star}=$ yellowness. 